\title{
Emergent Potato Leaf Spot Diseases in the Highland and Lowland Regions of Bolivia
}

\section{Coca Morante $\mathbf{M}^{*}$}

Plant Science and Plant Production Department, University of San Simón, Cochabamba, Bolivia

\begin{abstract}
In Bolivia, potato (Solanum tuberosum L.) leaf spot diseases have traditionally been regarded as of little importance especially in the Andean highlands. In recent years, however, new types of leaf spot disease have appeared, their distribution widened, and their incidence and severity increased. The present work identifies the main types of leaf spot present in the traditional highland growing regions of the Departments of La Paz (around $4350 \mathrm{~m}$ ) and Cochabamba (2900-4100 m), and in the north of the Department of Santa Cruz, the new lowland area of potato production (around $235 \mathrm{~m}$ ). Five causal agents were identified in the highland region: Alternaria solani, Septoria lycopersici, Cercospora solanicola, Passalora concors and Botrytis cinerea. These affected several types of native potato. In the lowland region, $A$. solani and Stagonospora spp. were found to cause leaf spot disease on $\mathrm{cv}$. Desireé. In both agroecosystems, the diseases sometimes appeared alongside late blight (caused by Phytophthora infestans). The leaf spot disease caused by $A$. solani, was very destructive, while that caused by $S$. lycopersici was only destructive in the highlands.
\end{abstract}

Keywords: Native potatoes; Disease intensity; Destructive disease

\section{Introduction}

Potato (Solanum tuberosum L.) leaf spot diseases are caused by different necrotrophic phytopathogens. They are sometimes confused with late blight, which is caused by Phytophthora infestans. Leaf spot diseases are most frequently seen in Bolivia's cold, damp Andean highlands (they are far less common in the warmer regions of the country), usually affecting native crops such as imillas (Solanum tuberosum subsp. andigena), bitter (Solanum $\times$ juzepczukii) and phurejas (Solanum phureja) potatoes [1]. Leaf spot diseases have also been recorded in the highland regions of Peru, Ecuador and Colombia [2-4]. According to Hooker [2], the causal agents in high altitude areas include Septoria lycopersici, Cercospora spp., Phoma andina, Ulocladium atrum and Botrytis cinerea, while Chaenophora cucurbitarum affects plants in the lowlands. Leaf spot diseases in the highland regions have traditionally been regarded as of little importance. However, in recent years their distribution and intensity (incidence and severity) have increased, as has the impact of late blight [5]. Other types of leaf spot disease are caused by Phoma andina and Phoma huancayense [4]. The leaf spot caused by $S$. lycopersici is regionally important in the Venezuelan, Peruvian and Ecuadorian Andes, from where reports of over $60 \%$ leaf destruction have been made [6,7]. Indeed, "septoriosis" has long been known to have serious effects [8]. In Bolivia, where it is known as khasahui, it is not a devastating disease, although it is of moderate importance and can cause early leaf death [3].

The main production areas of the Andean highlands in the Departments of La Paz $(>4000 \mathrm{~m})$ and Cochabamba $(>3500 \mathrm{~m})$ are permanently cloudy, very damp, and cold - typical of the transition zone between the lowlands and the Andean Region or Cordillera Real (Figure 1). In recent years, S. lycopersici has caused damage to potato crops in these areas, especially in the native imillas and Solanum $\times$ juzepczukii forms [5]. The distributions of this and other forms of leaf spot disease are now expanding, and types of leaf spot new to the highlands of Cochabamba have been recorded [9]. The present work describes the main forms of leaf spot in the highland regions of the Departments of La Paz and Cochabamba, and in a new, milder, lowland potato production area of Bolivia.

\section{Materials and Methods}

In January and February of 2012, 2013 and 2014, survey expeditions were made to record the leaf spot diseases affecting potato plants in Bolivia's traditional highland growing areas of the Departments of La Paz (around $4350 \mathrm{~m}$ ) and Cochabamba (2900-3300 m), and in the

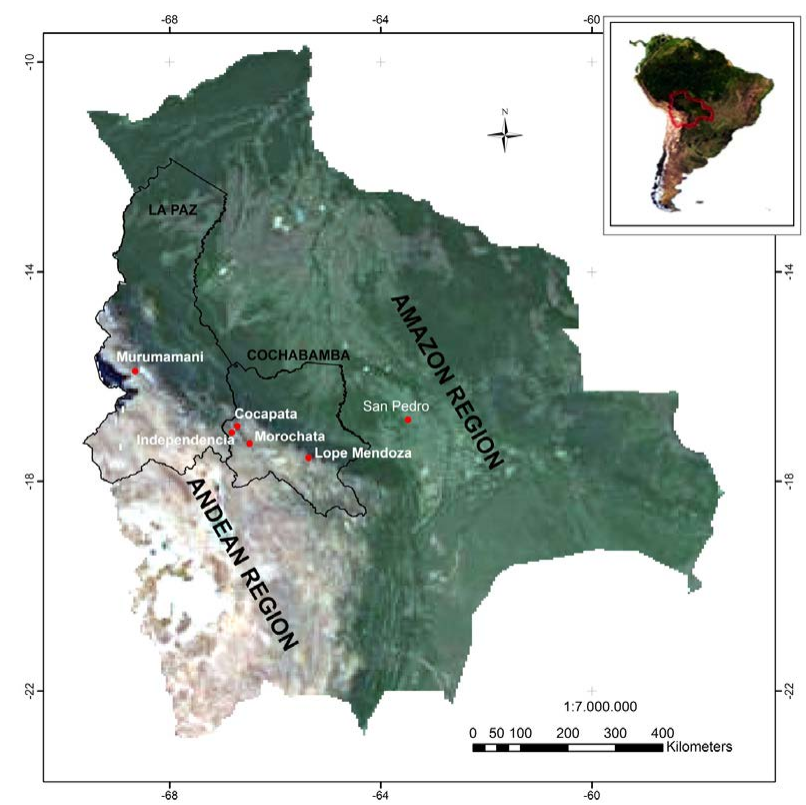

Figure 1: Sampling sites during the field surveys (red spots). (Map after CISTEL, Facultad de Ciencias Agrícolas y Pecuarias, UMSS).

*Corresponding author: Coca Morante M, Faculty of Agricultural Sciences, Livestock, Forestry and Veterinary, Plant Science and Plant Production Department, Cochabamba, Bolivia, Tel: 59144762383; Fax: 59144762385; E-mail: agr.mcm10@gmail.com

Received August 15, 2016; Accepted August 29, 2016; Published August 31, 2016

Citation: Morante C (2016) Emergent Potato Leaf Spot Diseases in the Highland and Lowland Regions of Bolivia. J Plant Pathol Microbiol 7: 372. doi: 10.4172/21577471.1000372

Copyright: (c) 2016 Morante C. This is an open-access article distributed under the terms of the Creative Commons Attribution License, which permits unrestricted use, distribution, and reproduction in any medium, provided the original author and source are credited. 
Citation: Morante C (2016) Emergent Potato Leaf Spot Diseases in the Highland and Lowland Regions of Bolivia. J Plant Pathol Microbiol 7: 372. doi: 10.4172/2157-7471.1000372

Page 2 of 6

\begin{tabular}{|c|c|c|c|c|c|c|}
\hline Department & Province & Area of influence & Locality & Altitude & Latitude & Longitude \\
\hline & & & & (m) & $\mathbf{s}$ & $\mathbf{w}$ \\
\hline \multirow[t]{3}{*}{ La Paz } & Omasuyos & Murumamani & Murumamani & 4300 & $15^{\circ} 54^{\prime} 0.00^{\prime \prime}$ & $68^{\circ} 39^{\prime} 0.00^{\prime \prime}$ \\
\hline & & & Humanata & 4250 & $15^{\circ} 52^{\prime} 41.15^{\prime \prime}$ & $68^{\circ} 38^{\prime} 49.37^{\prime \prime}$ \\
\hline & Camacho & Humanata & Humanata & 4150 & $15^{\circ} 28^{\prime} 28.82^{\prime \prime}$ & $69^{\circ} 7^{\prime} 20.24^{\prime \prime}$ \\
\hline \multirow{10}{*}{ Cochabamba } & Carrasco & Lope Mendoza & Escalante & 2950 & $17^{\circ} 31^{\prime} 55.49^{\prime \prime}$ & $65^{\circ} 22^{\prime} 55.32^{\prime \prime}$ \\
\hline & & & Chullchungani & 3050 & $17^{\circ} 33^{\prime} 39.15^{\prime \prime}$ & $65^{\circ} 20^{\prime} 6.75^{\prime \prime}$ \\
\hline & & & Phuyuhuasi & 3150 & $17^{\circ} 34^{\prime} 14.46^{\prime \prime}$ & $65^{\circ} 20^{\prime} 26.32^{\prime \prime}$ \\
\hline & & & Montepunku & 2950 & $17^{\circ} 35^{\prime} 10.76^{\prime \prime}$ & $65^{\circ} 18^{\prime} 27.14^{\prime \prime}$ \\
\hline & & & Laimetoro & 3100 & $17^{\circ} 39^{\prime} 4.00^{\prime \prime}$ & $65^{\circ} 6^{\prime} 30.52^{\prime \prime}$ \\
\hline & Ayopaya & Morochata & Piucilla & 3320 & $17^{\circ} 13^{\prime} 34^{\prime \prime}$ & 66 o $30^{\prime} 17^{\prime \prime}$ \\
\hline & Ayopaya & Independencia & Sensei & 3200 & $17^{\circ} 4^{\prime} 49.18^{\prime \prime}$ & $66^{\circ} 50^{\prime} 11.56^{\prime \prime}$ \\
\hline & & Cocapata & Choro & 4100 & $16^{\circ} 58^{\prime} 42.23^{\prime \prime}$ & $66^{\circ} 42^{\prime} 54.20^{\prime \prime}$ \\
\hline & Chapare & Coranipampa & Coranipampa & 2650 & $17^{\circ} 7^{\prime} 20.68^{\prime \prime}$ & $65^{\circ} 56^{\prime} 2.58^{\prime \prime}$ \\
\hline & & & Pairumani & 2600 & $17^{\circ} 7^{\prime} 54.35^{\prime \prime}$ & $65^{\circ} 56^{\prime} 8.47^{\prime \prime}$ \\
\hline Santa Cruz & Cordillera & Chane & San Pedro & 500 & $16^{\circ} 49^{\prime} 37.61^{\prime \prime}$ & $63^{\circ} 28^{\prime} 52.86^{\prime \prime}$ \\
\hline
\end{tabular}

Table 1: Locations where leaf samples were taken.

\begin{tabular}{|c|c|c|c|c|}
\hline Locality & Variety & Potato species & Common name of disease & Causal agent \\
\hline Murumamani & Waych'a & Solanum tuberosum subsp. andigena & Khasahui (septoriosis) & Septoria lycopersici \\
\hline Humanata & Rosita & Solanum tuberosum subsp. andigena & Khasahui (septoriosis) & Septoria lycopersici \\
\hline Humanata & Waych'a & Solanum tuberosum subsp. andigena & Khasahui (septoriosis) & Septoria lycopersici \\
\hline Escalante & Desireé & Solanum tuberosum subsp. tuberosum & EBLS & Alternaria solani \\
\hline Chullchungani & Desireé & Solanum tuberosum subsp. tuberosum & Mancha negra (EBLS) & Alternaria solani \\
\hline Phuyuhuasi & Desireé & Solanum tuberosum subsp. tuberosum & Mancha negra (EBLS) & Alternaria solani \\
\hline Montepunku & Desireé & Solanum tuberosum subsp. tuberosum & Mancha negra (EBLS) & Alternaria solani \\
\hline Laimetoro & Puka $\left({ }^{*}\right)$ & Solanum andigena $\mathrm{x}$ tuberosum & Manchón (leaf blotch) & Cercospora spp. \\
\hline Piucilla & Waych'a & Solanum tuberosum subsp. andigena & Mancha plateada (CLB) & Passalora concors \\
\hline Sensei & Waych'a & Solanum tuberosum subsp. andigena & Mancha negra (EBLS) & Alternaria solani \\
\hline Choro & Waych'a & Solanum tuberosum subsp. andigena & Khasahui (septoriosis) & Septoria lycopersici \\
\hline Coranipampa & Phureja & Solanum phureja & Gray mold & Botrytis sp. \\
\hline San Pedro & Desireé & Solanum tuberosum subsp. tuberosum & Mancha negra (EBLS) & Alternaria solani \\
\hline San Pedro & Desireé & Solanum tuberosum subsp. tuberosum & Mancha marrón (BLS) & Stagonospora sp. \\
\hline
\end{tabular}

$(*)=$ Puka Toralapa, an improved variety that shows inherent resistance, developed by the Estación

Experimental Toralapa, Instituto Boliviano de Tecnología Agropecuaria in 1980-1982. EBLS=Early Blight Leaf Spot. CLB=Cercospora Leaf Blotch. BLS=Brown Leaf Spot.

Table 2: Types of leaf spot diseases detected, where they were detected, and potato varieties affected.

north of the Department of Santa Cruz, the country's new, lowland growing region (San Pedro locality, around $500 \mathrm{~m}$ ) (Figure 1) (Table 1). In the Department of La Paz, leaf samples were collected in the communities of Murumamani, Humanata (both in the Province of Omasuyos) and Humanata (in the Province of Camacho) (Table 1). Given their proximity to the Andean peaks of the Cordillera Real mountain range, these communities are under permanent cloud, damp, and cold. In the Department of Cochabamba, samples were collected in the communities within the areas of influence of Lope Mendoza (in the Province of Carrasco), Morochata and Independencia (Province of Ayopaya), and Coranipampa (Province of Chapare) (Table 1). These areas have the same kind of climate as described above, a consequence of their proximity to the transition zones to the Andean region to Amazon region (Figure 1). In the Department of Santa Cruz, samples were collected in the area of Chané to the north of Santa Cruz (Province of Cordillera) (Table 1). Soybean (Glycine soja) and sugar cane (Saccharum officinarum) are extensively grown here; potatoes are grown during the winter (March to August). The climate at this time is mild to cold and damp, a consequence of cold winter winds arriving from Argentina.

In the highlands of the Departments of La Paz and Cochabamba, leaves showing signs of leaf spot disease (total $\mathrm{N}=10-20$ depending on the year) were collected from different plants growing in small holdings sown with native varieties such as Waych'a (a variety of imilla) ( $S$. tuberosum subsp. andigena), and phureja blanca (a variety of phureja) (S. phureja), and bitter potato (S. x juzepzukii). In the lowlands of Santa Cruz, similar samples (total $\mathrm{N}=10-20$ ) were collected from plants growing in extensive plots sown with variety Desireé (S. tuberosum subsp. tuberosum).

The collected samples were taken to the laboratory in plastic bags inside preservation boxes within two days, and the fungal reproductive structures stained with lactophenol methylene blue [10] and examined under a stereomicroscope. The fungi causing the leaf spot symptoms were identified using the taxonomic keys and indicators of different authors as indicated below.

\section{Results}

Six types of leaf spot were found affecting the native S. $t$. subsp. andigena and introduced S. t. subsp. tuberosum (Table 2).

\section{Early blight leaf spot caused by Alternaria solani sorauer}

This was detected in the highlands of Cochabamba near Escalante, Chullchungani, Phuyuhuasi and Montepunku (in the Lope Mendoza area, Province of Carrasco). It was also detected in the lowland area of the Department of Santa Cruz at San Pedro (in the Chane area) (Table 2). In both agroecosystems the climate during the growing period is 
damp and largely cold $\left(8-18^{\circ} \mathrm{C}\right)$. In the highlands it affected the native variety Waych'a (S. tuberosum subsp. andigena), while in the lowlands if was found on variety Desireé (S. tuberosum subsp. tuberosum). In all the places it was detected alongside (i.e., on the same plant or even the same leaf) late blight (caused by $P$. infestans). Incidence was generalized in both agroecosystems, and the disease more severe in cv. Desireé.

The characteristic symptom was the formation of dark brown leaf spots surrounded by a halo that becomes more obvious with time (Figures 2A and 2B). In Waych'a they were more angular and irregular, limited by the veins and the interior of the spots showed discontinuous, irregular rings (Figure 2A). In cv. Desireé, the spots were more circular and regular, larger, and the inner rings more notable (Figure $2 \mathrm{~B}$ ).

Within the spots, small, dark brown, superficially growing structures were seen, formed from small clusters of conidiophores, straights and, septate (Figure 2C). Dark conidia formed at the apices of the latter, solitary, slightly flexuous with the body of the conidium ellipsoidal tapering to a beak which is same length as longer than the body, pale or dark brown, smooth, with 9 or more transverse and 0 longitudinal or oblique septa; beak is flexuous (Figure 2D). Using the keys of Ellis [11], the fungus was identified as A. solani.

Septoria leaf spot (khasahui) caused by Septoria malagutii ciccar. and Boerema ex E.T. Cline, sp. nov. (Syn. Septoria lycopersici speg.)

This was identified in samples from the Departments of La Paz and Cochabamba collected at an altitude of around $4100 \mathrm{~m}$ (Table 2). In both of these highland agroecosystems, the conditions are damp and cold $\left(7-15^{\circ} \mathrm{C}\right)$ during the growing season (November to May). In the Department of La Paz, it was detected in the Murumamani area in the communities of Murumamani, Paconi and Umanata, where it affected the native varieties Waych'a and the bitter potato (variety Luk'ys) (Solanum $x$ juzepzukii) (Table 2). In the Department of Cochabamba it was identified in the areas of Cocapata and Choro (Province of Ayopaya), and in the community of Phuyuhuasi within the Lope Mendoza area (Province of Carrasco), where it affected the variety Waych'a (Table 2). In all these areas the disease appeared alongside (i.e., on the same plant or leaf) late blight. In Murumamani (Dept. of

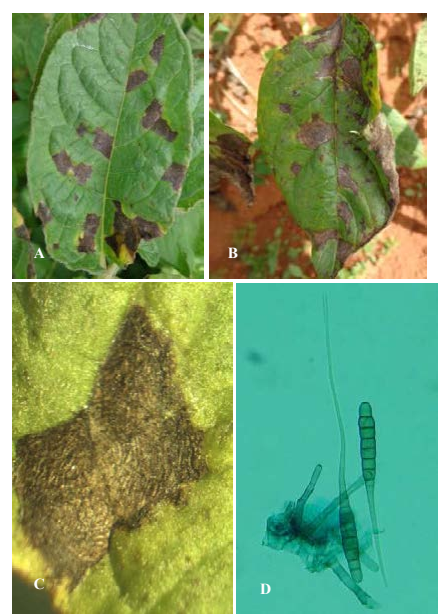

Figure 2: Leaf spot caused by Alternaria solani on the native and introduced potatoes varieties. A: Angular form of lesion on the variety Waych'a ( $S$. tuberosum subsp. andigena). B: Circular to irregular lesions on variety Desiree (S. tuberosum subsp. tuberosum). C: Formation of irregular rings in the lesions (Mag. 75X). D: Conidiophores in small clusters, straights and conidia are ellipsoidal tapering to a beak same length as longer than the body (Mag. 400X).

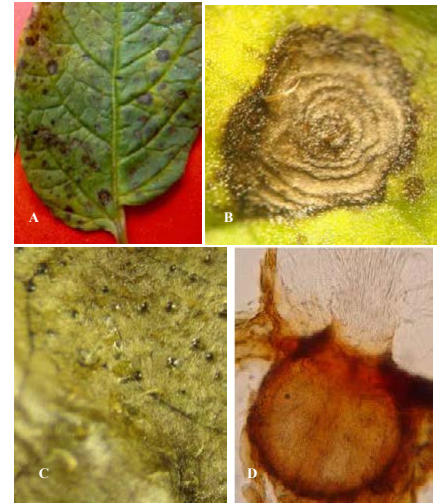

Figure 3: Leaf spot caused by Septoria lycopersici in the native variety Waych'a (S. tuberosum subsp. andigena). A: Small circular lesions on the leaf. B: Formation of irregular, concentric rings in the lesion (Mag. 50X). C: Formation of pycnidia (Mag. 100X). D: Pycnidia immersed in the tissue releasing elongated, hyaline-colored conidia through the ostiole (Mag. 400X). The conidia are hyaline, filiform, or occasionally straight.

La Paz) and Choro (Dept. of Cochabamba), the disease was sometimes destructive.

The spots were small (1-5 mm), circular to irregular, dark brown, and with concentric, irregular rings (Figures $3 \mathrm{~A}$ and $3 \mathrm{~B}$ ). At first these spots appear isolated from one another, but over time coalesce, giving rise to lesions similar to those seen in late blight. Small (although visible with the naked eye) blackish pycnidia were seen at the center of the spots (Figure 3C). The pycnidial conidiomata were epigenous, solitary, scattered with several per lesion, immersed in the epidermis, and just visible $(<100 \mu \mathrm{m}$ in diameter). The ostiole was brown-black and some 45-70 $\mu \mathrm{m}$ diameter. The conidia were hyaline, filiform, slightly curved, occasionally straight or sigmoid, sharply pointed at both ends, and sometimes slightly rounded at the base. The apex was rounded when the conidia were still attached $(90 \pm 4.4[50-122] \mu \mathrm{m}$ long $\times 1.9 \pm 0.03$ [1.0-2.0] $\mu \mathrm{m}$ wide). There were 4-7 septa with no constrictions (Figure 3D). Using the keys of Cline and Rossman [1], the fungus was identified as Septoria malagutii.

\section{Leaf blotch caused by Cercospora spp. Atk.}

This was detected in plants in the Laimetoro area (Province of Carrasco) in the Department of Cochabamba (Table 2), affecting (in isolation) the native varieties Waych'a and Chaucha blanca (Solanum chaucha) and the improved variety Puka toralapa (Hybrid Solanum tubersoum variety with $\mathrm{R}$ genes). Cloud cover is permanent in this area, the humidity is high, and the temperatures between 5 and $15^{\circ} \mathrm{C}$. Where the humidity is very high the disease can become destructive.

The characteristic symptoms included damp-looking angular and circular-to-irregular spots, sometimes coalescing to form blotches similar to those caused by late blight (Figure 4A). The disease affected both the leaves and shoots. The spots themselves showed just-visible, irregular, concentric rings. The center of the leaf on both sides had a whitish felt-like covering (Figures $4 \mathrm{~B}$ and $4 \mathrm{C}$ ) formed by the fruiting structures of the fungus, i.e., clusters of conidiophores (Figure 4D) and acicular conidia (hyaline in color) (Figure 4D). The conidiophores emerged through the stomata, were unbranched, subcylindrical to geniculate-sinuous, appeared in small, dense fascicles, and showed dimensions of up to $70 \times 5.5 \mu$. The conidia were slightly curved, pale olivaceous, smooth, with 6-8 septa, and with dimensions of up to $82 \times 5.5 \mu$. The keys of Chupp [12], Ellis [11] and Braun and Crous [13] identified the causal agent as Cercospora spp. 
Citation: Morante C (2016) Emergent Potato Leaf Spot Diseases in the Highland and Lowland Regions of Bolivia. J Plant Pathol Microbiol 7: 372. doi: 10.4172/2157-7471.1000372

\section{Grey mold caused by Botrytis cinerea Pers.:Fr.}

This was identified in leaves (only) of plants in the Coranipampa area (Province of Chapare, Municipality of Colomi) in the Department of Cochabamba (Table 2). The climate here is temperate to warm temperate (foothill climate). The disease affected the phureja blanca variety (S. phureja), but with just a few spots, and appeared alongside late blight. The disease appeared as isolated, damp-looking, blackish spots, circular to irregular in shape. The tissue bordering the spots was slightly chlorotic (Figures $5 \mathrm{~A}$ and $5 \mathrm{~B}$ ). On the underside of the leaves, a lead-gray woolly carpet was seen (Figure 5B), made up of sporangiophore clusters and spores (Figures 5C and 5D). The conidiophores were 1.5-2.2 mm long, branched, with a stipe, and had a rather open head. They are smooth, clear brown below, paler near the apex, and with the ends of the branches quite colorless. The conidia were ellipsoid or obovoid in shape, with a slightly protuberant hilum, colorless to pale brown, smooth, and of dimensions $8-12 \times 6-10 \mu$. using the keys of Ellis [11], the fungus was identified as Botrytis cinerea Pers.

\section{Cercospora leaf blotch caused by Passalora concors (Casp.)} Sacc. (Syn. Cercospora concors (Casp.) Sacc.

This disease affected the leaves of native Waych'a Paceña plants (S. tuberosum subsp. andigena), commonly alongside late blight. The severity of infection ranged from $10-20 \%$ (determined using Image Analysis software). The lower to middle leaves were preferentially affected, with symptoms starting as yellowish-green, circular to irregular blotches on the upper leaf surface (Figure 1A). Gradually the centers of these blotches become grey to black with a soft yellow halo (Figure 1B). A fluffy grey layer of conidiophores and conidia eventually forms on the abaxial surface of the leaves, (Figures 1C and 1D). Hyphae were observed growing over the leaf hairs (Figures $1 \mathrm{D}$ and $1 \mathrm{E}$ ). The conidiophores occurred in dense fascicles above the stomata; these were irregular in width, grayish, and highly branched (Figure 1F). The conidia were variable in size, catenate and slightly curved, obclavate, pale olivaceous, smooth, non-septate, and 12-16 $\mu$ in length $\times 3-6 \mu$ in width (Figure 1F). Using the keys of Ellis [11] and Crous and Braun [14], the fungus was identified as Passalora concors, a synonym of Cercospora concors (Casp.) (Crous). This is the first report of this pathogen causing Cercospora leaf blotch in the Andean highlands of Bolivia.

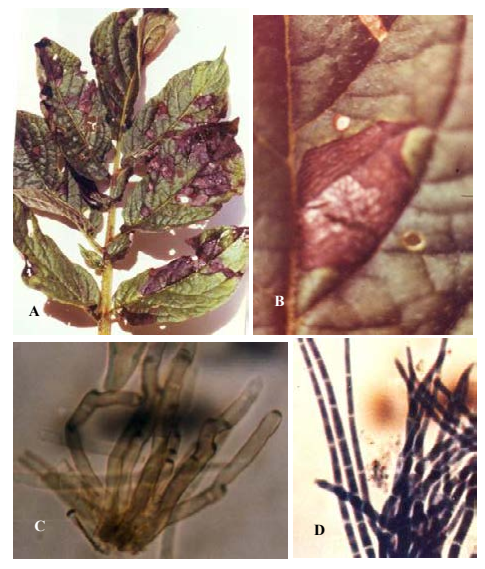

Figure 4: Leaf spot caused by Cercospora solanicola in the variety Puka toralapa (an improved variety that shows resistance to $P$. infestans). A: Circular to irregular lesions of damp, blackish appearance (Mag. 50X). B: Lesion showing irregular rings and the growth of a felt-like, whitish carpet in the central area. C: Conidiophore in cluster formation (Mag. 400X). D: Elongated, septate conidia stained with methylene blue (Mag. 400X).

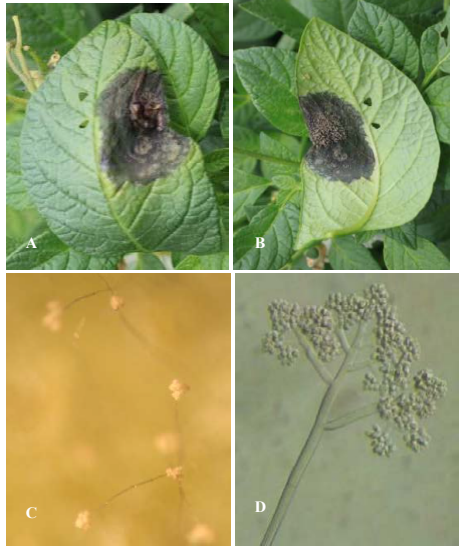

Figure 5: Leaf spot caused by Botrytis spp. in the native variety phureja blanca (Solanum phureja). A: Dark lesion on the upper leaf surfauce. B: Lesion on the underside of the leaf showing a gray carpet-like growth. C: Conidiophores showing spore cluster formations (under the stereomicroscope, Mag. 100X); D: Conidiophore with clustering conidia (Mag. 400X).

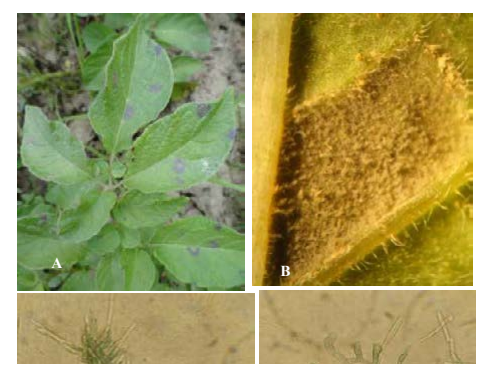

Figure 6: Leaf spot caused by Passalora concors in the native variety Waych'a (S. tuberosum subsp. andigena). A: Circular to irregular lesion light colored lead on the upper side of the leaf. B: Lead-gray carpet of fungus on the underside of the leaf as downy mildew (under the stereomicroscope, Mag. 50X). C: Trichome on the underside of a leaf showing fungal growth (Mag. 400X). D: Conidiophore in the stromatic body and elongated hyaline conidia (Mag. 400X).

\section{Brown leaf spot caused by Stagonospora spp. (Sacc.) Sacc.}

This was detected in cv. Desireé plants growing in the area of Chane (Province of Cordillera) in the north of the Dept. of Santa Cruz (Table 2) during the winter (March-August). The climate in this area is damp and temperate to temperate-cold $\left(10-20^{\circ} \mathrm{C}\right)$, a consequence of cold winter winds blowing in from Argentina. Spots were few in number, and appeared alongside those caused by $A$. solani. The characteristic symptom is the formation of dark brown irregular spots with marked brown edges, that become elongated by coalescence (Figure 6A) and which may then acquire a yellowish halo (Figure 6A). Small, light or dark brown fruiting bodies (pycnidia) were visible within the spots (Figure 6B), partially embedded in necrotic tissue (Figure 6B). The conidia, released from the ostiole, were elongated (Figure 6C), hyaline to clear brown in color, and with several transverse septs (Figure 6D) and (Figure 7).

\section{Discussion}

The six causal agents of leaf spot diseases reported in this work are A. solani [11], S. malagutii [1], Cercospora spp. [12], Ellis [11], $P$. concors [14]; Ellis [11], B. cinerea [15], and Stagonospora spp. [16]. All have been reported in other Andean countries and indeed other regions of the world [2-4,8,9,17-20]. Stagonospora spp. is a new causal of agent of leaf spot in lowland Bolivia.

Most of the leaf spot diseases affecting Bolivia's potato crops were 
Citation: Morante C (2016) Emergent Potato Leaf Spot Diseases in the Highland and Lowland Regions of Bolivia. J Plant Pathol Microbiol 7: 372. doi: $10.4172 / 2157-7471.1000372$

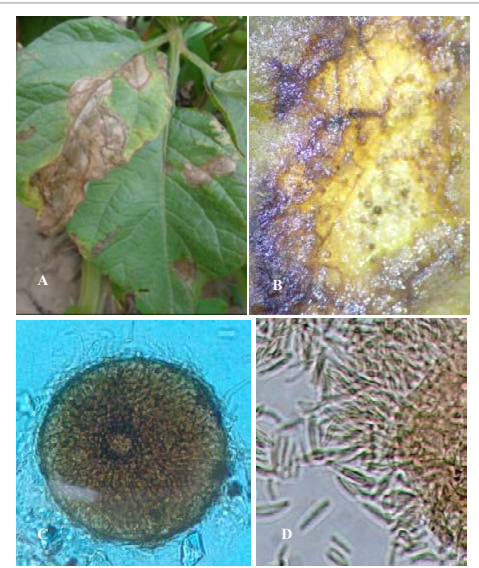

Figure 7: Leaf spot caused by Stagonospora spp. in the variety Desiree $(S$. tuberosum subsp. tuberosum). A: Irregular, clear-brown, elongated lesion on the upper side of the leaf. B: Formation of small pycnidia on the leaf surface (red arrow). C: Microscopic view of the pycnidia (Mag. 400X). D: Conidia with 2-4 septs (Mag. 600X).

found in the damp and cold highland areas of the Departments of La Paz and Cochabamba. This agrees with that reported by Turkensteen [4], Hoopes and Sage [3] and Hooker [2], who indicate them to be appear in Andean Bolivia, Peru, Ecuador and Colombia. In the lowland area examined leaf spot disease was also found, but much less commonly; this agrees with that reported by Hooker [2]. A relationship appears to exist between the appearance of disease and altitude/environmental conditions (dampness and cold temperatures). Note that khasahui, caused by Septoria malagutii (a synonym of $S$. lycopersici) was the only disease at altitudes of over $4000 \mathrm{~m}$. Coca-Morante [9] indicates that this disease can cause $40 \%$ losses of production in high areas of the Department of La Paz. In addition, Torres [20] indicates that the spots caused by this disease appear in cold, wet areas at altitudes of 3800-400 $\mathrm{m}$. However, Hooker [2], indicates that in Venezuela the disease occurs at $1600-2500 \mathrm{~m}$, while in Ecuador it is reported to be seen mostly at over $3000 \mathrm{~m}$ [7].

The diseases caused by A. solani, Cercospora spp., P. concors and B. cinerea appeared in highland areas between 2600 and $3300 \mathrm{~m}$ in the Departments of La Paz and Cochabamba. That caused by Stagonospora spp. appeared at $250 \mathrm{~m}$ in the lowlands of Santa Cruz. Early blight caused by A. solani is found worldwide wherever potatoes are grown [2]. Neither leaf blotch caused by Cercospora spp., nor gray mold caused by $B$. cinerea, have been previously reported in the Bolivian Andes. Grey mold is usually considered of minor economic importance in the region [2].

In the present work, leaf blotch caused by $P$. concors (Casp.) Sacc (Syn. C. concors [Casp.] Sacc.) was destructive under high humidity and cool temperatures. It has been previously reported in the highlands of Cochabamba [9]. It is also known in cool areas of Europe, the former Soviet Union, North America, in some restricted areas of Africa and Asia, and has recently been reported from China [21]. This disease is considered of minor importance, and may occur simultaneously with late blight (caused by P. infestans) or early blight (caused by A. solani).

Until now, Stagonospora spp. has never been reported to cause disease in Bolivia. For the time being it is of minor importance, and normally occurs simultaneously with other potato leaf disease such as late blight.
The present results suggest that leaf spot diseases in Bolivia should be monitored in order to prevent possible losses of production.

\section{Acknowledgements}

The author is grateful to ASDI-DICYT-UMSS for financial support of the Project "Evaluación del impacto de las variaciones climáticas en el manejo de la enfermedad tizón tardío de la papa en zonas endémicas altoandinas del departamento de Cochabamba, Bolivia "over 2010-2012. Thanks are also owed to Javier Burgos Villegas, principal investigator at the Centro de investigación en Sistemas y Teledetecion (CISTEL), Facultad de Ciencias Agricolas y Pecurias "Dr. Martin Cárdenas", Universidad Mayor de San Simón, for map production and the collection of samples in the field. The authors also thank the farmers of the Piucilla-Morochata, Lope Mendoza, Laimetoro, Choro-Cocapata and Chane areas for the help received during this work, and Adrian Burton for editorial assistance and valuable comments and suggestions.

\section{References}

1. Erica TC, Amy YR (2006) Septoria malagutii sp. nov., cause of annular leaf spot of potato. Mycotaxon 98: 125-135.

2. Hooker WJ (1990) (Ed.) Compendium of potato diseases. The American Phytopathological Society. St. Paul, Minnesota, EUA p: 60.

3. Hoopes RW, Sage C (1982) Factores que restringen la producción de papa en Bolivia perspectivas para su mejoramiento. Consorcio para el Desarrollo Internacional/Departamento de Geografía Universidad de Dirham Reino Unido. Cochabamba, Bolivia.

4. Turkensteen LJ (1978) Tizón Foliar de la Papa en el Perú: I Especies de Phoma Asociadas. Fitopatología 13: 67-69.

5. Coca-Morante M, Castillo-Plata W, Méndez Á (2014) Control químico de septoriosis (Septoria lycopersici Speg.) de la papa (Solanum tuberosum subsp. andigena) en zonas altoandinas de altura de Bolivia. Revista Latinoamericana de la Papa 18: 116-121.

6. Carrera J, Orellana H (1978) Estudio de la Mancha Foliar de la Papa Septoria lycopersici Sub-grupo A. en el Ecuador. Fitopatología 13: 51-57.

7. Cabi E (1984) Data sheets on quarantine organisms $N^{\circ} 142$, Septoria lycopersici var. malagutii. Bulletin OEPP/EPPO 14: 43-49.

8. Jiménez AT, French ER (1972) Mancha Anular Foliar (Septoria lycopersic Subgrupo A) de la papa. Fitopatología 5: 15-20.

9. Coca Morante MC (2014) First Report of Passalora concors (Casp.) Causing Cercospora Leaf Blotch in the Andean Region of Cochabamba, Bolivia. J Plant Pathol Microb 5: 221

10. French ER, Hebbert TT (1980) Métodos de Investigación Fitopatológica. Instituto Interamericano de Ciencias Agrícolas. San José, Costa Rica p: 289.

11. Ellis MB (1971) Dematiaceous Hyphomycetes. Commonwealth Mycological Institute. Kew, Surrey, England p: 608.

12. Chupp C (1954) A monograph of the fungus genus Cercospora. Ithaca, New York p: 667.

13. Braun U, Crous PW (2007) The diversity of cercosporoid hyphomycetes new species, combinations, names and nomenclatural clarifications. Fungal Diversity 26: 55-72.

14. Crous PW, Braun U (2003) Mycosphaerella and its anamorphs: 1. Names published in Cercospora and Passalora. CBS Biodiversity Series 1: 1-571.

15. Elad Y, Williamson B, Tudzynski P, Denle N (2007) Botrytis: Biology, Pathology and Control. Kluwer Academic Publisher. P.O. Box 17, 3300 AA Dordrecht, The Netherlands p: 403.

16. Sutton BC (1980) The Coelomycetes: Fungi Imperfecti with Pycnidia, Acervuli and Stromata. Commonvealth Mycological Institute. Kew, Surrey, England p: 696.

17. Gandarillas A, Ortuño NY (2009) Compendio de enfermedades, insectos nematodos y factores abióticos que afectan al cultivo de la papa en Bolivia. Fundación PROINPA. Cochabamba, Bolivia p: 181.

18. Otazu V, Brown WM, Quitón MH (1984) Enfermedades de las plantas en Bolivia. Ministerio de Asuntos Campesinos y Agropecuarios, Instituto de Tecnología Agropecuaria, Consorcio Internacional para el Desarrollo. Cochabamba, Bolivia p: 31.

19. Turkensteen (1981) Compendium of Potato Diseases: Cercospora lea blotches or Cercospora leaf spots. American Phytopathological Society p: 65. 
Citation: Morante C (2016) Emergent Potato Leaf Spot Diseases in the Highland and Lowland Regions of Bolivia. J Plant Pathol Microbiol 7: 372. doi: $10.4172 / 2157-7471.1000372$

Page 6 of 6

20. Torres H (2002) Otras enfermedades foliares. En: Manual de las enfermedades más importantes de la papa en el Perú. Centro Internacional de la Papa. Lima, Perú p: 86
21. Tian SM, Ma P, Liu DQ, Zou MQ (2008) First Report of Cercosporaconcors Causing Cercospora Leaf Blotch of Potato in Inner Mongolia, North China. Plant Disease 92: 4-654. 